\title{
増大傾向を示した舌下腺による静止性骨空洞の長期観察例
}

\author{
軽部健史 ${ }^{1,2)}$ ·安居孝純 ${ }^{2)}$. 鬼澤勝弘 ${ }^{2)}$

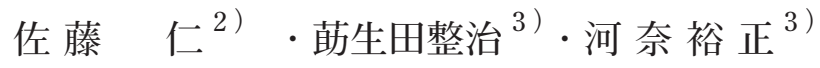

\section{A long-term followed-up case of a developing lingual bone defect associated with the sublingual gland}

\author{
KARUBE Takeshi $^{1,2)} \cdot$ YASUI Takazumi $^{2)} \cdot$ ONIZAWA Katsuhiro $^{2)}$ \\ SATO Hitoshi ${ }^{2)} \cdot$ ASODA Seiji $^{3)} \cdot$ KAWANA Hiromasa $^{3)}$
}

\begin{abstract}
Lingual bone defects are usually asymptomatic local concavities of the lingual cortical bone of the mandible, frequently caused by soft-tissue inclusion. In most cases, the soft tissue is the submandibular gland. Only 7 cases of developing lingual bone defects were previously reported in Japan, but none of these cases involved the sublingual gland. We report a rare case of a developing lingual bone defect associated with the sublingual gland, which we followed up for 21 years. The patient was a 58 -year-old man who had a developing lingual bone defect in the anterior right side of the mandible. A panoramic X-ray film showed an oval radiolucent area in the apical region of the lower right canine and first premolar tooth. Moreover, electric pulp testing confirmed that all teeth in the lower-right quadrant were vital. A panoramic X-ray film obtained at a nearby dental clinic demonstrated a radiolucent area 15 years before presentation to our department, and the area showed evidence of gradual expansion. Computed tomography revealed a local concavity in the lingual cortical bone of the right side of the mandible. The concavity measured $13 \times 9 \mathrm{~mm}$. The signal intensity of the inner tissue of the bone defect was nearly equivalent to that of the sublingual gland on T1-, T2-weighted magnetic resonance imaging. The suspected clinical diagnosis was a lingual bone defect. We performed an incisional biopsy to rule out a neoplastic lesion, and the histopathological diagnosis was normal sublingual gland tissue. On the basis of these results, the final diagnosis was a developing lingual bone defect associated with the sublingual gland. Two years have elapsed, but there is no swelling or induration in the right sublingual gland. The radiolucent area on the panoramic X-ray film showed decreased radiolucency and increased bone volume. Moreover, computed tomography revealed that the concavity of the bone had shrunk.
\end{abstract}

Key words: lingual bone defect (静止性骨空洞), developing (増大傾向), sublingual gland (舌下腺)

\begin{abstract}
緒
静止性骨空洞は，下顎骨の舌側皮質骨に生ずる限局性の 陷凹で，通常無症状に経過する。その陥凹部には擷下腺の 陷入が認められる場合が多く, 舌下腺の陥入はまれであ る。また,「静止性」という名称ではあるものの, きわめ
\end{abstract}

\author{
てまれに増大傾向を示すものも報告されている， \\ 今回，われわれは増大傾向を示した舌下腺による静止性 \\ 骨空洞の 1 例を, 21 年間にわたり長期経過観察し得たので \\ 文献的考察を加えて報告する。
}

1) 国家公務員共済組合連合会立川病院歯科口腔外科 (主任 : 木津英樹部長)

2) 川崎市立川崎病院柬科口腔外科 (主任：鬼澤勝弘部長)

3) 慶應義塾大学医学部茵科・ 口腔外科学教室 (主任：中川種昭教授)

${ }^{1)}$ Department of Dentistry and Oral Surgery, Federation of National Public Service Personnel Mutual Aid Associations, Tachikawa Hospital (Chief: Dr. KIZU Hideki)
${ }^{2)}$ Department of Dentistry and Oral Surgery, Kawasaki Municipal Kawasaki Hospital (Chief: Dr. ONIZAWA Katsuhiro)

${ }^{3)}$ Department of Dentistry and Oral Surgery, School of Medicine, Keio University (Chief: Prof. NAKAGAWA Taneaki) 受付日：2015年 8 月 7 日 採択日：2016年 3 月 29 日 

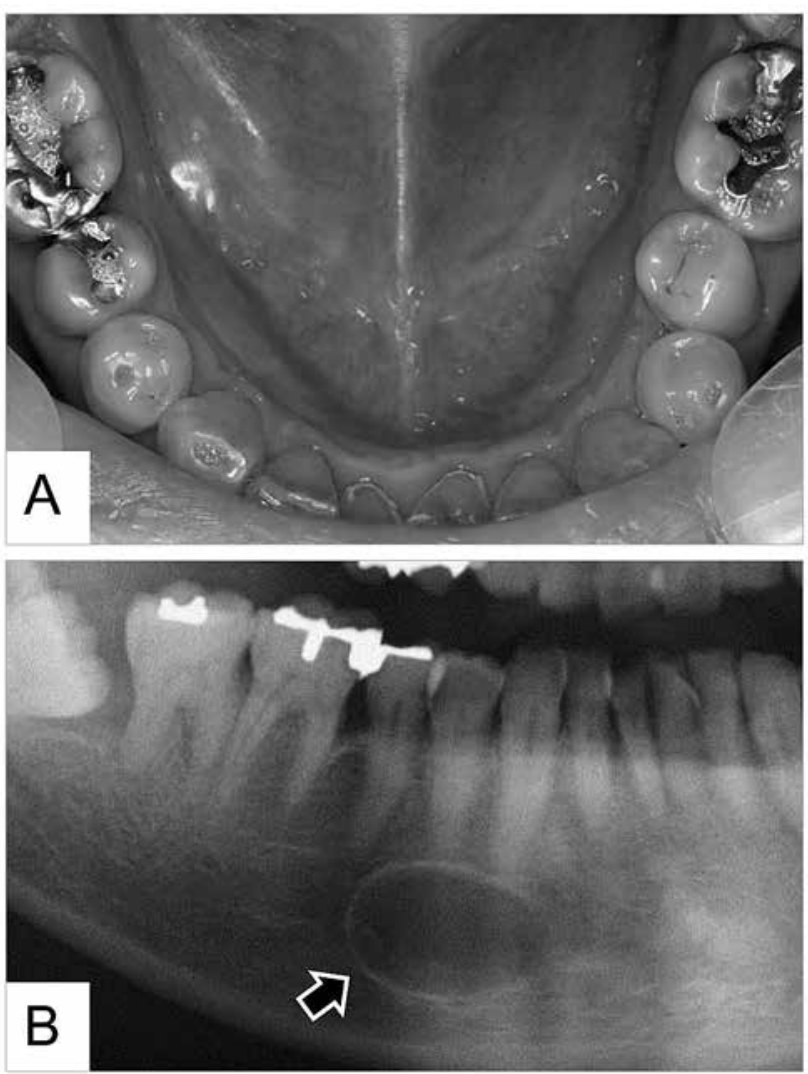

写真 1 初診時口腔内およびパノラマX X 線写真

A：顎骨膨隆および周囲㐘肉や粘膜の異常所見は認められな い。また口底部に左右差はなく, 硬結も認められない。

B：2013 年; 緻密な X 線不透過帯で囲まれた拇指頭大の類 円形透過像が認められる (矢印).

\section{症例}

患 者: 58 歳, 男性.

初 診: 2013 年 3 月.

主 訴：右側下顎骨の X 線透過像の精查.

既往歴: 高血圧症, 35 歳時より糖尿病. 外傷などの既 往はなく, 特記すべき口腔習癖もなかった。

家族歴：特記事項なし。

現病歴：2013 年 3 月に, かかりつけ茵科医院を受診し た際に, パノラマ X 線写真で $\overline{543}$ 根尖相当部に拇指頭 大の透過像を指摘され，精查目的に当院を紹介された。

現 症:

全身所見；体格中等度。栄養状態良好。

口腔外所見; 顔貌は左右対称で他の特記事項はなかった。 また, オトガイ神経領域の知覚鈍麻は認められなかった。

口腔内所見 ; 543 部に顎骨の膨隆打よび周囲菌肉の異 常所見は認められず,すべて生活菊で骨植は良好であった。 また口底部組織に左右差はなく, 粘膜は健常色で舌下腺と その周囲組織に硬結も認められなかった（写真 $1 \mathrm{~A})$ ）。唾液 流出の異常もなかった.
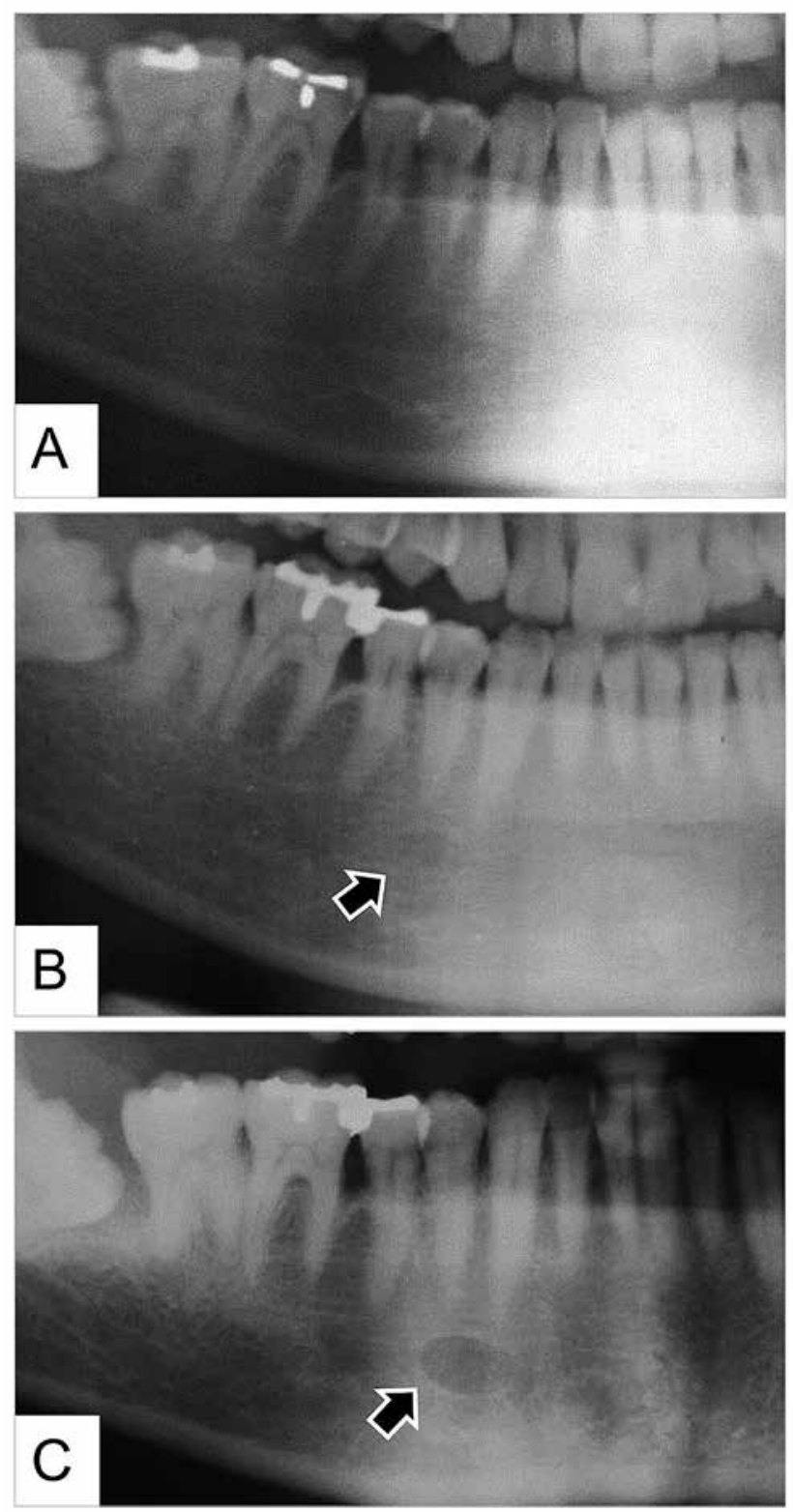

写真 2 パノラマX X 線写真の経過

A：1994 年 (初診 19 年前); 透過像は認められない.

B：1998 年 (初診 15 年前) ; 小豆大の淡い透過像を認め始 める (矢印).

C：2004 年 (初診 9 年前) ; 緻密な不透過帯に囲まれた大 豆大の透過像が認められる (矢印).

画像所見 :

パノラマ X 線所見 ; $\overline{543}$ の根尖部に境界明瞭で, $\mathrm{X}$ 線 不透過帯で囲まれた拇指頭大の類円形透過像が認められた (写真 1B).

かかりつけ㐘科医院で撮影された過去のパノラマ X 線写 真の経時的変化を確認すると, 1994 年 (初診 19 年前) の 写真では明らかな透過像は認められなかった (写真 $2 \mathrm{~A})$. しかしながら, 1998 年 (初診 15 年前) には, 4 根尖部に 


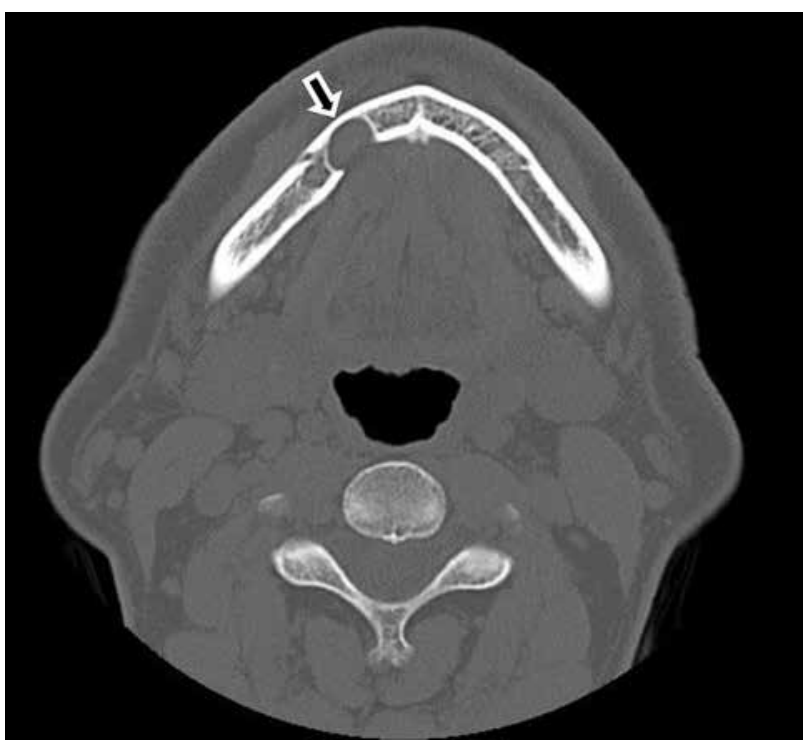

写真 $3 \mathrm{CT}$ 画像 (水平断像)

$\overline{54}$ の舌側面に $13 \times 9 \mathrm{~mm}$ 大の境界明瞭な類円形の 骨陥凹部が認められる (矢印)。

小豆大の淡い透過像を認め (写真 2B), 2004 年（初診 9 年 前）には周囲に緻密な不透過帯に囲まれた大豆大の透過像 が明瞭に認められた (写真 2C)。 また, 当科初診の 2013 年 では透過像の範囲は拡大していることから, 類円形透過像 の経時的な増大が明らかに確認できた。

CT 所見 ; $\overline{54}$ 舌側面に $13 \times 9 \mathrm{~mm}$ 大の境界明瞭な類 円形の骨陥凹が認められた (写真 3$)$ 。内部は脂肪組織や舌 下腺と同程度の density を示していた。

MRI 所見; 骨陥凹部は舌下腺と連続した組織で満たさ れ，ガドリニウム造影後 $\mathrm{T} 1$ 強調像では舌下腺の造影効果 に左右差はなく, 均一であった（写真 4).

臨床診断：静止性骨空洞の疑い。

処置および経過：臨床所見打よび画像所見より静止性骨 空洞を強く疑ったが，増大傾向を示していたため 2013 年 3 月に局所麻酔下に生検術を施行した。術中所見では，右 側下靧骨舌側に限局性の骨陥凹が認められ，同部に入り込 むように硬結を伴わない舌下腺と思われる組織が認められ た。骨との関係性を把握するために，陥凹部を満たしてい る軟組織を骨面全体より剥離し，一部を採取した。骨との 剥離は容易であった。病理組織学的所見では，正常舌下腺 組織であり, 経過観察を行うこととした。生検後 2 年経過 した現在，右側舌下腺の腫脹や硬結は認められず，パノラ マX 線写真では透過性が減弱し, 骨増生が認められた（写 真 5A）。CTでは陥凹部の明らかな縮小が認められた（写 真 $5 B$ ).

病理組織学的所見：粘液性腺房に富む正常な舌下腺組織

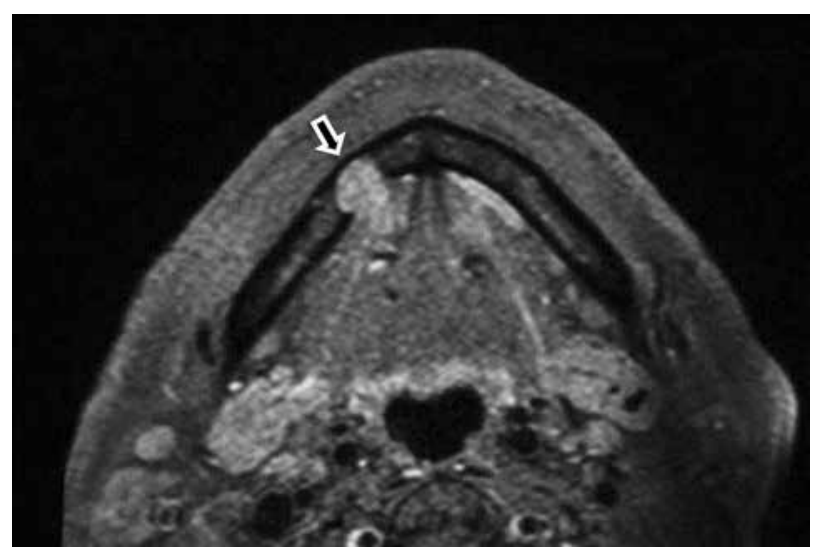

写真 4 MR 画像

ガドリニウム造影 $\mathrm{T} 1$ 強調像 (水平断像)；骨陥凹部は, 舌下腺と連続した内部組織で満たされ，ガドリニウムに よる舌下腺の造影効果に左右差はなく均一である（矢印 は内部組織を示す)。
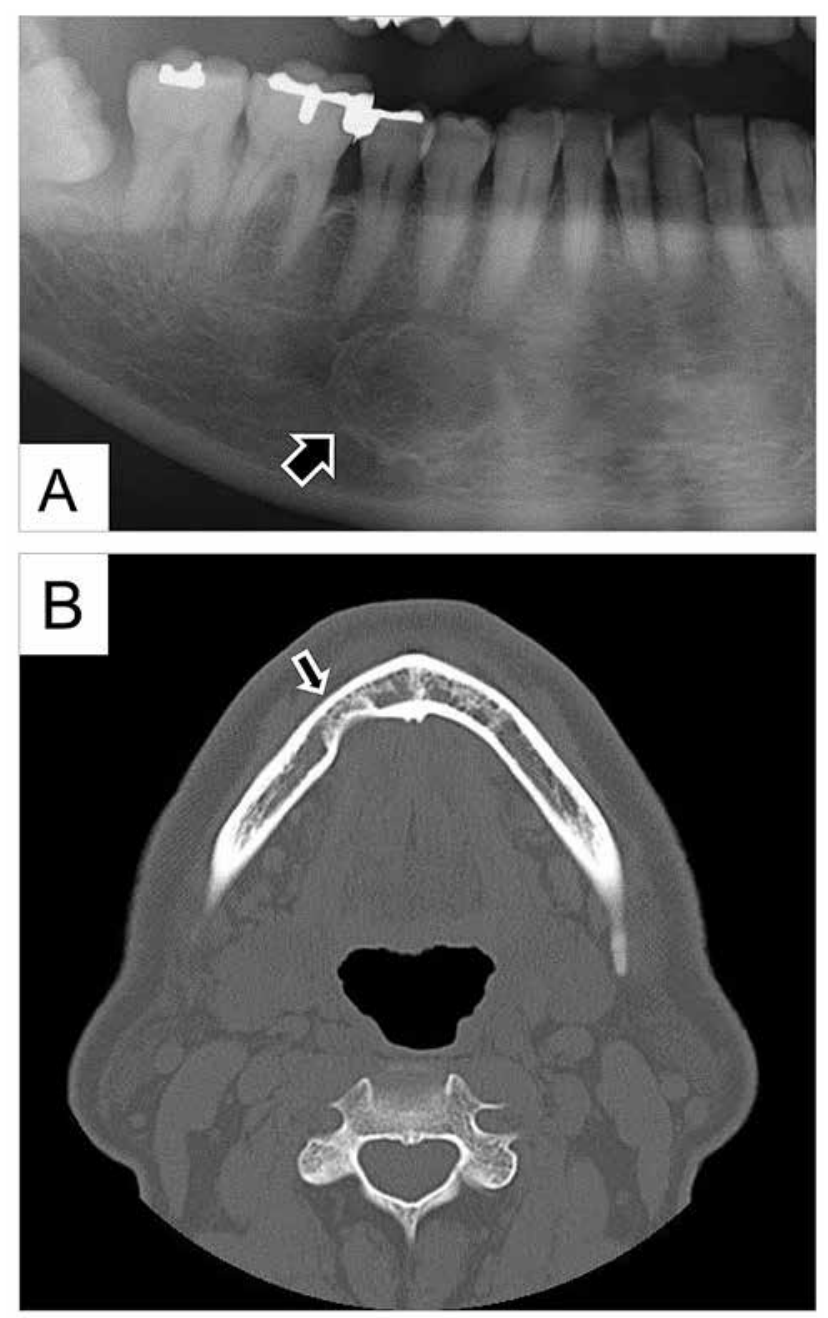

写真 5 生検後 2 年のパノラマ X 線写真および $\mathrm{CT}$ 画像 (水平断像)

A：透過性の減弱が認められる (矢印).

B：骨陥凹部の明らかな縮小が認められる (矢印). 


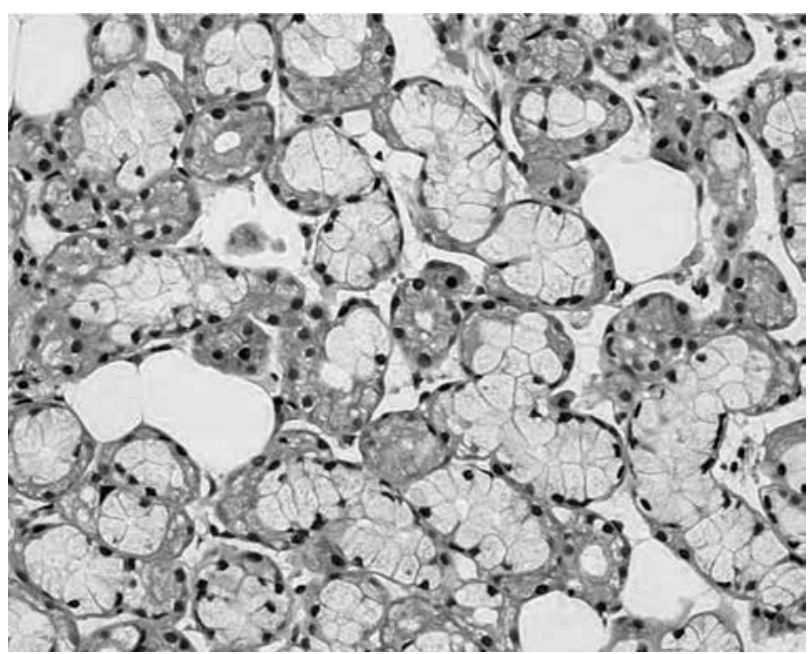

写真 6 病理組織像 $(H-E$ 染色 $\times 200)$ 粘液性腺房に富む正常な腺組織で, 腫瘍性変化は認め られない。

\section{がみられた (写真 6$)$.}

病理組織学的診断：舌下腺による静止性骨空洞.

\section{考察}

静止性骨空洞は，下顎角部の下顎管下方で周囲を緻密な $\mathrm{X}$ 線不透過帯で囲まれた類円形の境界明瞭な囊胞様骨欠損 として，1942 年にStafne ${ }^{1)}$ により初めて報告された。一般 にパノラマX線写真に扎いて発見されることが多く，その 発生率は $0.08 \sim 0.7 \%$ でる ${ }^{2,3)}$. 性差は男性に多く, 年齢 は 40〜50 歳代に多くみられ, 自験例も同様であった。発 症部位は, Philipsen ら ${ }^{4)}$ によると大臼㐘部抢よび下顎角 部に多く認められ，583 例中 497 例 $(85.2 \%)$ であったとし， 自験例のような犬柬から小臼柬部の症例は 72 例 $(12.3 \%)$ と少なかったとしている。成因についてはStafne の軟骨残 遺説, Fordyce の顎骨発育途上の異常説 ${ }^{5}$ ), Rushtonの孤 立性囊胞萎縮説 ${ }^{6}$ ), Thoma の動脈瘤説 ${ }^{7)}$, Choukas の顎 下腺圧迫による浸蝕・迷入説 ${ }^{8)}$, Harvey の外科刺激説 $\left.{ }^{9}\right)$ などのさまざまな見解がある。また，40～50 歳代に認めら れた報告例が多いことから，限局した後天性骨欠損と考え られる。

骨欠損部に陥入した組織は，過去の報告より唾液腺が大 部分を占めている。われわれが渉猟し得た限りでは，本邦 で病理組織学的に骨空洞内組織を確認できたものは自験例 を含めて 43 例 10 2 23) で，そのうち唾液腺が最も多く30 例 $(69.8 \%)$ で,リンパ組織，結合組織，脂肪組織などが続 いている. 各唾液腺の内訳は擷下腺が 21 例, 舌下腺が 7 例, 不明が 2 例である.

本邦において，下顎前方部に生じた舌下腺による静止性
骨空洞の報告は 7 例 11 17) で, 平均年齢は 38.7 歳ですべ て男性であった。部位は片側の犬柬から小四柬部に多く， 両側に認められた骨空洞は 3 例で, そのうち 2 例は正中 を越えており, 骨空洞の大きさは10～90 mm 大であった. 処置は 2 例が生検術, 4 例が摘出術, 1 例に下顎骨辺縁切 除術が行われていた。部位が特徴的でないため, CT P MRI が活用される以前には, やや過剩な外科的介入が行わ れる傾向がみられた。転帰については，4例が経過良好で, その他は不明であり, 経過年数は 6 か月〜 2 年であった。

増大傾向を示した静止性骨空洞は, 組織を確認できた 43 例の報告のうち 7 例 18２3）であった。このうち, 骨空洞内 組織が舌下腺であったものは，われわれが渉猟し得た限り 自験例のみであった。

増大傾向を示した静止性骨空洞 7 例の詳細についてであ るが，平均年齢は 45.3 歳で，5例が男性であった。部位は すべて第二大臼菊より後方に位置しており，骨空洞の大き さは $10 〜 35 \mathrm{~mm}$ 大であった。骨空洞内組織は正常唾液腺 組織が 3 例, リンパ節と脂肪組織が 2 例であり, 脂肪組織, リンパ組織がそれぞれ 1 例ずつであった。正常唾液腺組織 はいずれも顎下腺であった。処置は 1 例の生検術を除き， その他のすべてで摘出術が行われていた。転帰は骨欠損の 縮小や消失が認められたものが 5 例で，その他の骨欠損縮 小の有無は不明で, 経過年数は 9 か月〜 3 年 6 か月であっ た。長期経過観察された報告は少なく，自験例が 21 年間 と最長であった。

静止性骨空洞が増大傾向を示す理由については, 一定し た見解は得られていないが, 骨空洞内組織による圧迫が最 も考えやすい。その一因として, 唾液腺症による唾液腺の 増大が考えられる。唾液腺症は唾液腺実質の代謝ないし分 泌障害に基づく非炎症性・非腫瘍性の疾患であり，無痛性 腫脹をきたす。関連疾患として, 糖尿病や慢性膵炎などが 挙げられる. Maria ら ${ }^{24)}$ は, 糖尿病による糖代謝障害に 伴い, 腺房細胞が腫大することで顎下腺が形態学的変化を 呈したことを報告している。自験例では既往歴に糖尿病が あるため唾液腺増大の一因となった可能性があるが, 画像 所見では舌下腺の大きさに左右差を認めず，明らかな増大 は認められなかった。西原ら ${ }^{25)}$ は, 口腔関連の習㾕と顎 骨の形態変化について検討しているが, 自験例では自覚は ないものの舌癖や煩杖などの習癖により, 舌下腺によって 骨が圧迫され㫟凹した可能性も否定できない。

一方, 生検を行いX線透過像が縮小した理由については, 舌下腺によって下顎骨へ加わっていた圧力が生検時に行っ た骨面からの剥離により解放され, 骨形成が促進されたこ とが考えられる。依然, 静止性骨空洞の増大や生検による 縮小の理由には不明な点が多いため, 症例報告を蓄積し検 討を重ねる必要があると思われる。 
静止性骨空洞の診断には, CT P MRI などの画像検査が 有用であり，とくにMRI は組織分解能が高く，軟組織の 描出に適している ${ }^{26,27)}$. 自験例では, 舌下腺から連続し た像が認められ, 骨空洞内組織と周囲組織との関係を把握 するのに有用であると考えられた。通常，パノラマX線写 真に打いて診断され, 無症状に経過するため, それ以上の 検索をなされることは少ない. そのため, 外科的処置など の積極的な治療は不要とされてきたが, その病態から, 必 ずしも静止性ではなく, 自験例のように増大傾向を示す場 合がある。静止性か否かの判断は一時点ではできず，経時 的な観察により診断可能となる。したがって，いずれの症 例においても長期的な経過観察が重要となる。本疾患が増 大することはまれではあるが, 増大傾向が認められる際は 腫瘍性病変との鑑別のために生検を含めた外科的処置を考 慮することが必要である。

自験例に扎いては，過去に撮影されたパノラマX 線写真 の記録より，明らかな増大傾向が認められたため生検術を 施行した。骨空洞内組織が正常舌下腺組織であったため, 患者の希望をふまえて定期的なパノラマ X 線写真撮影によ る長期的な経過観察を行うこととした。生検後 2 年経過し た現在, パノラマX線写真に打ける透過性の減弱が認めら れ経過良好である。

\section{結語}

今回，われわれは増大傾向を示した舌下腺による静止性 骨空洞のまれな長期観察例を経験したので, 文献的考察を 加えて報告した。

謝辞

稿を終えるにあたり, 自験例の診断, 病理組織学的所見につ いての御助言, 御指導を賜りました川崎市立川崎病院病理検 査科の入江理恵先生に深謝致します。

本論文に関して，開示すべき利益相反状態はない.

\section{引用文献}

1) Stafne EC : Bone cavities situated near the angle of the mandible. J Am Dent Assoc 29: 1969-1972, 1942.

2 ) Assaf AT, Solaty M, et al : Prevalence of Stafne's bone cavity - retrospective analysis of 14,005 Panoramic views. In Vivo 28: 1159-1164, 2014.

3 ) Schneider T, Filo K, et al : Stafne bone cavities: systematic algorithm for diagnosis derived from retrospective data over a 5-year period. Br J Oral Maxillofac Surg 52: 369-374, 2014.

4 ) Philipsen HP, Takata T, et al : Lingual and buccal mandibular bone depressions: a review based on 583 cases from a world-wide literature survey, including 69 new cases from Japan. Dentomaxillofac Radiol 31: 281-290, 2002.
5 ) Fordyce GL: The probable nature of so-called latent haemorrhagic cysts of the mandible. Brit Dent J 101: 40-42, 1956.

6 ) Rushton $\mathrm{MH}$ and Cantab $\mathrm{BCh}$ : Solitary bone cysts in the mandible. Brit D J 81: 37-49, 1946.

7 ) Thoma KH : Case report of a so-called latent bone cyst. Oral Surg 16: 703-712, 1955.

8 ) Choukas NC and Toto PD : Etiology of static bone defect of the mandible. J Oral Surg 18: 16-20, 1960.

9 ) Harvey W and Noble HW : Defects on the lingual surface of the mandible near the angle. Br J Oral Surg 6: 75-83, 1968.

10）佐藤泰則, 埜口五十雄, 他：嚬下腺造影により診断 した静止性骨空洞の 1例. 日口外誌 34: 1437-1443, 1988.

11）有家 巧, 森田章介, 他：下顎前㐘部にみられた静 止性骨空洞の 1 例. 日口外誌 42: 941-943, 1996.

12）川端泰三, 水野明夫, 他：下顎骨前方部舌側にみら れた静止性骨空洞類似の骨欠損の 1 例. 日口外誌 29: 102-107, 1983.

13）和田 明, 林 洋紀, 他：静止性骨空洞の 6 例. 日 口診誌 30: 185-191, 1984.

14）若杉正則, 北川善政, 他： 543 部にみられた静止 性骨空洞の 1 例。日口外誌 37: 518-523, 1991.

15）松野智宣, 熊澤康雄, 他：舌下腺により満たされた 静止性骨空洞の 1 例. 蒾学 82: 719-723, 1994.

16）道向英二, 原 潤一, 他：下顎前方部に生じた静止 性骨空洞の 1 例。尾道総合病院医報 11: 41-44, 2001.

17）岩崎佳見, 清水香澄, 他： 34 根尖部にみられた静 止性骨空洞の 1 例。 日口診誌 24: 59-62, 2011.

18）池本公亮, 石川武憲, 他：Stafne 氏静止性骨空洞の 2 症例一病態と手術に関する考察一. 日口外誌 35 : 2716-2722, 1989.

19）猪俣 徹, 足立雅利, 他：増大傾向を示した静止性 骨空洞の 1 例. 日口診誌 24: 397-401, 2011.

20）平田貴士, 村田 琢, 他: 発育傾向を示した静止性 骨空洞の 1 例。 日診誌 $13: 447-450,2000$.

21）吉沢栄子, 浅田洸一, 他：下嚬枝部にみられたい わゆる静止性骨空洞の 1 例. 日口外誌 40: 628-663, 1994.

22) Shibata H, Yoshizawa N, et al : Developmental lingual bone defect of the mandible. report of case. J Oral Maxillofac Surg 20: 328-329, 1991.

23）水野 進, 大田充彦, 他: 経年的に骨欠損が増大 した静止性骨空洞の 1 例. 愛院大茵誌 52: 490-495, 2014.

24) Maria AL, Paola S, et al : Diabetes causes morphological changes in human submandibular gland: a morphometric study. J Oral Pathol Med 44: 291-295, 2015.

25）西原克成, 赤川徹弥：口腔に関連する習癖と顎口腔 疾患について。日口診誌 4: 360-383, 1991.

26）有地栄一郎, 田端修, 他：いわゆる Stafne's bone cavity 3 例の CTによる検索. 口科誌 37: 303-315, 1988.

27) Branstetter BF, Weissman JL, et al : Imaging of Stafne bone cavity: What MR adds and why a new name is needed. Am J Neuroradiol 20: 587-589, 1999. 